\title{
SEJARAH DAKWAH DI MAKASSAR
}

\section{Syamsuri}

Dosen Pada Jurusan Komunikasi dan Penyiaran Islam IAIN Palu

\section{Abstract :}

This paper deals with the Islamic da'wah in Makassar. Islam in this area is coincided with the culture and structure of society. Those who hold an authority are forced to go hand in hand with society to concern with Islam in order to be regarded as "pious and religious". A variety of symbols are displayed as a scenario to please people. Such symbols are a dome of mosque, religiosity, pilgrimage (hajj), 'umrah, and designation of "guru mengaji" (religious teacher). Cultural Islam has a great impact on those in auhtority as an agent. Along with the history of da'wah in Makassar, history always forces those in authority to go in and out as a moment of creating image, and da'wah was made as commodity.

$$
\begin{aligned}
& \text { ويقوم هذا البحث بقضية الدعوة الإسلامية في مقسر. وفى هذه المنظقة ، يتشى الإسلام مع ثقافة و بنيان }
\end{aligned}
$$

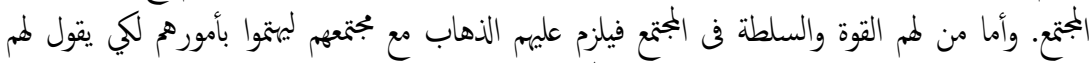

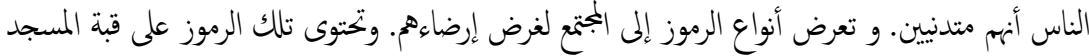

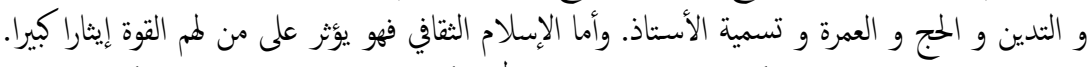

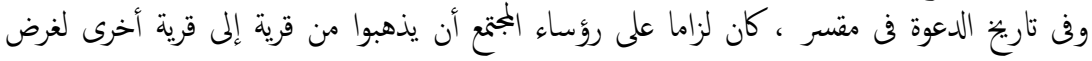

$$
\begin{aligned}
& \text { البحث عن الثناء ، وتعتبر الدعوة فيها سلعة. }
\end{aligned}
$$

Kata Kunci : Islam, kultur, struktur masyarakat.

\section{Pendahuluan}

Nama "Makassar" sudah termaktub di dalamnya ada pengaruh Islam terhadap ibukota Propinsi Sulawesi Selatan itu. Mattulada mengintrodusir salah satu asal usul nama Makassar yaitu sebuah ungkapan "Makkasara'mi Muhammad di buttaya ri Tallo" (Nabi Muhammad menjelma atau menampakkan diri di Kerajaan Tallo). Ungkapan tersebut tidaklah bisa dipahami secara tekstual, bahwa Nabi Muhammad sendiri yang langsung membawa agama Islam ke Makassar. 
Ungkapan itu harus diinterpretasikan bahwa ajaran Nabi Muhammad atau Islam telah masuk dalam kalbu orang Makassar. ${ }^{1}$

Hal ini dapat pula dinisbahkan bahwa kata "Makassar" berasal dari bahasa Arab yaitu menqasar (meringkaskan empat rakaat shalat menjadi dua rakaat, seperti shalat Dhuhur dan shalat Ashar yang masing-masing empat rakaat tapi dalam keadaan musafir lalu dikerjakan hanya masing-masing dua rakaat dan dikerjakan pada waktu Dhuhurtaqdim atau pada waktu Ashar-ta'khir). Konon kabarnya, muballig yang pertama kali tiba di tempat itu pada waktu sore, sehingga ia melakukan Shalat Qasar pada waktu Ashar.

Penghargaan Makassar terhadap Islam terlihat pula pada peringatan hari lahir kota itu yang jatuh pada setiap tanggal 9 Nopember. Pada tahun 2013, Makassar memperingati hari jadinya yang ke-406. Tonggak awal kelahiran Kota Makassar pada tanggal 9 Nopember 1607 adalah hari Jumat. Pada hari itu dilaksanakan proklamasi Islam sebagai agama Kerajaan Gowa Tallo. Pada saat itu diadakan shalat Jumat bersama pertama di masjid Tallo.

Nama-nama Islam kerap dipakai untuk penamaan lembagalembaga prestisius di Makassar seperti Bandar Udara Internasional Sultan Hasanuddin, padahal Raja Gowa ke-16 ini memiliki nama Makassar yaitu I Mallombassang Daeng Mattawang Karaeng Bontomangape Tomenanga ri Ballapangkana. Perguruan tinggi terbesar di Indonesia Timur yaitu Universitas Hasanuddin dan Universitas Islam Negeri (UIN) Alauddin. Sultan Alauddin adalah Raja Gowa ke-14 memiliki pula nama Makassar yaitu I Mangarangi Daeng Manrabia Tominanga ri Gaukanna.

Perjalanan dakwah di Makassar tidak bisa lepas dari kondisi sosial, budaya dan politik. Semangat ber-Islam untuk melepaskan diri dari tekanan kaum kafir menyulut semangat ulama dan pengikutnya untuk angkat senjata melawan penjajah. Oleh karena itu, refleksi

${ }^{1}$ Mattulada, Menyusuri Jejak Kehadiran Makassar Dalam Sejarah, (Makassar: Universitas Hasanuddin, 1983), h. 221. 


\section{$\Delta$ L-nis $H \exists \vec{\Delta}$ H. Vol. 10 No. 1, Januari-Juni 2014:01-20}

perjalanan dakwah di Makassar, penulis membagi beberapa fase, yaitu (1) fase awal masuknya agama Islam, (2) fase kedatangan tiga orang muballig (3) fase ideologisasi, (4) fase pengaruh Syekh Yusuf, (5) fase masuknya organisasi Muhammadiyah dan Nahdlatul Ulama (NU), (6) fase Orde Baru, dan (7) fase Reformasi. Namun dalam tulisan ini hanya menguraikan perjalanan dakwah Islam dalam tiga fase saja yakni fase awal masuknya Islam, fase kedatangan tiga orang muballigh dan fase ideologisasi Islam di Makassar dan sekitarnya.

\section{Pembahasan}

\section{A. Fase awal Masuknya Islam}

Pertama kali Makassar bersentuhan dengan Islam berkat jasa para pedagang yang mengunjugi pelabuhan maritim Makassar. ${ }^{2}$ Ada pedagang muslim yang menjadikan pelabuhan Makassar sebagai tujuan utama perdagangan dan ada pula yang menjadikan sebagai pelabuhan transit menuju kawasan timur nusantara. Mengenai waktu masuknya Islam di Makassar ditetapkan berdasarkan masuknya Islam di nusantara, karena wilayah ini tidak pernah terlepas dari determinan perjalanan bangsa Indonesia. Artinya apa yang terjadi di pusat pemerintahan itu juga yang terjadi di Makassar.

Ada tiga teori masuknya Islam di nusantara, yaitu Teori Gujarat, Teori Makkah dan Teori Persia. ${ }^{3}$ Teori Gujarat menyatakan bahwa masuknya Islam di nusantara pada abad XIII. Artinya kurang lebih 600 tahun setelah Nabi Muhammad SAW meninggal dunia, baru Islam masuk di nusantara. Teori Makkah menyebut kedatangan Islam di nusantara pada abad VII. Artinya semasih Nabi Muhammad SAW lahir atau kurang lebih pada masa Khulafaurrashidin (Abu Bakr Așsiddiq, Umar bin Khațtab, Uthman bin Affān dan Ali bin Abi Talib), Islam sudah masuk di nusantara. Sedangkan Teori Persia menitikberatkan pada alur

${ }^{2}$ Kini bernama Pelabuhan Laut Internasional Soekarno Hatta.

${ }^{3}$ Ahmad Mansur Suryanegara, Menemukan Sejarah, (Bandung : Mizan, 1995),

h. 74 . 
masuknya Islam di nusantara dengan melihat beberapa tradisi Shi'ah di Indonesia. Masuknya Islam di Makassar, sebagaimana ditulis oleh beberapa penulis sejarah, secara umum menunjuk pada Teori Gujarat. Teori ini menunjukkan bahwa orang yang membawa Islam di nusantara adalah pedagang Gujarat yang sudah memeluk agama Islam.

Teori Makkah dapat diperhitungkan karena muatannya dapat meningkatkan etos keagamaan masyarakat Makassar. Teori ini menunjukkan bahwa Islam masuk di nusantara (Makassar bagian terpenting di dalamnya) pada abad VII yang langsung dibawa oleh orang Arab. Orang Arab bagi Makassar identik dengan Islam dan Nabi Muhammad SAW, sebuah cerita mengungkapkan bahwa jamaah haji asal Makassar begitu mendarat di Bandar Udara Internasional King Abd Aziz Jeddah lalu berada di tempat pengambilan bagasi, buruh pengangkut barang langsung diraih tangannya lalu dicium karena dianggap mereka itu adalah cucu Nabi Muhammad SAW, karena memakai gamis dan kaifiyah (lilitan sorban di kepala seperti yang selalu dikenakan Yasser Arafat ketika masih hidup). Ketika kita menonton pertandingan olah raga di televisi, tim official dari Timur Tengah tetap mengenakan gamis dan kaifiyah seperti yang dikenakan oleh Raja Arab Saudi, Raja Bahrain, Emir Kuwait dan lain-lain.

Ada beberapa fakta yang dapat ditunjukkan bahwa Islam masuk di Makassar semasa Nabi Muhammad SAW memimpin negara Madinah atau Khulafurrāshidin. Sebuah hikayat di Palu Sulawesi Tengah yang mengungkapkan bahwa Sawerigading hidup bersamaan satu masa dengan Nabi Muhammad SAW. Danau Talaga yang terletak di Desa Talaga Kecamatan Damsol Kabupaten Donggala terjadi karena bekas injakan telapak kaki Sawerigading. Tokoh legenda ini adalah hikayat populis Kerajaan Luwu (kini menjadi Kabupaten Luwu Propinsi Sulawesi Selatan).

Kerajaan Luwu sudah berdiri sejak tahun 800 Masehi. ${ }^{4}$ Ini menandakan bahwa terciptanya sebuah negeri merupakan akumulasi

${ }^{4}$ H.M. Taliu, Sekilas dari Sebagian Kerajaan Otonomi yang pernah ada di Sulawesi Selatan, (Pangkajenne Kepulauan, Dinas Pendidikan Nasional, 2003), h. 5. 


\section{$\Delta$ L-nis $H \exists \vec{\Delta}$ H. Vol. 10 No. 1, Januari-Juni 2014:01-20}

dari peradaban manusia selama bertahun-tahun sehingga ada di antara mereka dapat menjadi pemimpin, Karya tulis di Kerajaan Luwu berupa surat I Lagaligo semakin mengukuhkan pandangan bahwa wilayah Sulawesi dengan pelabuhan maritim yang terkanal Makassar sudah ada kontak dengan pedagang Arab dari Hadramaut (Republik Yaman, berada di ujung Selatan jazirah Arab-sama dengan Makassar yang berada di ujung Selatan jazirah Sulawesi) Kedua negeri ini sama-sama berada di pesisir laut yang berbentuk selat).

Orang Arab dari Hadramaut kini banyak bertempat tinggal di Makassar seperti marga Al-Aidid di Cikoang Kabupaten Takalar yang terkenal dengan tradisi perayaan maulid dengan mengerahkan kapalkapal laut yang berisi penganan beras ketan (pulut) dengan lauk ayam dan telur serta hiasan warna warni memenuhi layar perahu. Marga Alsaqqāf (baca Assagāf) banyak bermukim dan bermakam di Kecamatan Bontoala di Makassar. Generasi dari Arab itu sudah banyak menempati pos jabatan penting di pemerintahan dan perusahaan. Di Kabupaten Bone Sulawesi Selatan terdapat makam Arab di Pallime, wilayah pesisir segitiga sungai Cenrana yang mengalirkan air Danau Tempe ke Selat Bone yang berhubungan langsung dengan Kerajaan Luwu dan Kerajaan Islam Buton di Propinsi Sulawesi Tenggara.

Jika Teori Gujarat hendak dicarikan bukti artefaknya di Makassar, maka kita akan berkata bahwa kita belum menemukan koloni orang India muslim di Makassar. Produksi dakwah dari India seperti Jamaah Tablig tidak semeriah penerimaannya dengan orang Arab yang memimpin lembaga-lembaga tarekat. Klimaksnya, Ahmadiyah yang berasal dari India sudah difatwakan oleh Majelis Ulama Indonesia (MUI) Pusat sebagai bukan dari ajaran Islam.

Dengan demikian besar harapan bahwa Islam masuk di Makassar pada masa Nabi Muhammad SAW Menurut Matulada, asal usul nama Makassar yaitu sebuah ungkapan "Makkasara'mi Muhammad di Buttaya ri Tallo" (Nabi Muhammad menjelma atau menampakkan diri di Kerajaan Tallo) 
Kerajaan Gowa yang berbasis di pedalaman (kini menjadi Kabupaten Gowa beribukota Sungguminasa) bersekutu dengan Kerajaan Tallo (kini bernama Kecamatan Tallo Kota Makassar) berbasir pesisir laut, memiliki otoritas penuh atas Makassar. Mattulada menyebut persekutuan Kerajaan Gowa-Tallo dengan sebutan Kerajaan Makassar, namun yang populer adalah Kerajaan Gowa. Pada komposisi yang hampir sama dengan penyiaran Islam di nusantara yaitu kekentalan penganut Islam di kawasan kerajaan pesisir. Hal tersebut sangat beralasan karena sarana transportasi yang masyhur adalah kapal laut. Oleh karena itu kerajaan-kerajaan pesisir yang menjadi sasaran dan transit perdagangan juga dimanfaatkan oleh para pedagang muslim untuk memperkenalkan Islam kepada masyarakat yang didatangi dan tentunya ketika terjadi transaksi jual beli.

Sebagai kerajaan pantai, daerah ini memberikan peluang kepada penduduknya untuk mencari penghasilan melalui laut. Pekerjaan sebagai pelaut dan saudagar telah berlangsung sejak abad XV dan lebih intensif lagi pada awal abad XVI. Kegiatan perdagangan dan perantauan yang berlangsung terus menerus, menyebabkan sosialisasi ajaran Islam menjadi cair dan berlangsung secara humanis, karena tidak dengan sebuah misi khusus menyiarkan agama Islam.

Setelah melihat antusias orang-orang Makassar, para pedagang yang merangkap sebagai juru dakwah sadar akan keterbatasan mereka untuk "mengawal" keberlangsungan ajaran Islam seperti pendidikan baca tulis Alqurān, pendidikan fiqh, pendidikan tauhid dan studi agama Islam lainnya sebagai syarat pemahaman dan pengamalan Islam yang paripurna. Oleh karena itu, para pedagang "sepakat" mengundang ulama untuk secara profesional mendakwahkan dan mengajarkan agama Islam ${ }^{5}$.

${ }^{5}$ Pada setiap kegiatan dakwah selalu diikuti kegiatan pendidikan dan pengajaran. Di zaman Nabi Muhammad SAW, di rumah Arqam bin Arqam diadakan pendidikan tentang ajaran Islam. Hal itu memang hal yang lumrah terjadi karena sewaktu memeluk Islam, maka orang itu akan mengenal lebih jauh tentang Islam seperti aqidah, syariah dan muamalah. Di beberapa daerah kita menjumpai di mana terdapat ulama besar mendakwahkan Islam, maka tidak luput di tempat itu berdiri lembaga pendidikan Islam. 


\section{$\Delta$ L-nis $H \exists \bar{\Delta}$ H H Vol. 10 No. 1, Januari-Juni 2014:01-20}

\section{B. Fase Kedatangan Tiga Orang Muballig}

Ulama yang didatangkan ke Makassar adalah Datuk ri Bandang, Datuk Patimang dan Datuk ri Tiro. Dalam memulai kegitan dakwah mereka mempelajari terlebih dahulu kondisi sosial budaya di Kerajaan Gowa-Tallo. Ahmad M. Sewang mengemukakan bahwa Datuk ri Bandang dan temannya ketika tiba di Makassar, tidak langsung melaksanakan misinya, tetapi lebih dahulu menysun strategi dakwah. Mereka menanyakan kepada orang-orang Melayu yang sudah lama bermukim di Makassar tentang raja yang paling dihormati. ${ }^{6}$

Setelah mereka melakukan penjajakan di Kerajaan Gowa Tallo, lalu menyebar untuk menjalan misi dakwah, yaitu :

1. Abdul Makmur, Khatib Tunggal, yang lebih populer dengan nama Datuk ri Bandang yang dikenal sebagai ahli fikih bertugas untuk menghadapi masyarakat Gowa dan Tallo yang masih berpegang kuat pada tradisi lama, seperti perjudian, minum ballo' (tuak), dan sabung ayam. Dalam menghadapi masyarakat demikian, metode dakwah yang dipakai Datuk ri Bandang lebih menekankan pada masalah pelaksanaan hukum shari'at.

2. Sulaiman, Khatib Sulung, yang lebih populer dengan nama Datuk Patimang, bertugas di Kerajaan Luwu yang masyarakatnya masih kuat berpegang kepada kepercayaan lama, seperti Dewata seuwae. Datuk Patimang memperkenalkan ajaran tauhid yang sederhana dengan mengemukakan sifat-sifat Tuhan, seperti sifat wajib, sifat mustahil dan sifat ja'iz bagi Tuhan. Penekanan pada ajaran tauhid ini dimaksudkan untuk mengganti kepercayaan Dewata Seuwae menjadi keimanan kepada tauhid, yaitu Allah Yang maha Esa.

3. Abdul Jawad, Khatib Bungsu, yang lebih dikenal dengan nama Datuk ri Tiro $^{7}$ bertugas di daerah Tiro, Bulukumba, dengan

${ }^{6}$ Ahmad M. Sewang, Islamisasi Kerajaan Gowa Abad XVI Sampai Abad XVII, (Jakarta : Yayasan Obor Indonesia, 2005), h. 91.

${ }^{7}$ Pemberian gelar kepada ketiga muballig di atas menarik untuk diamati. Walaupun sebagai suku Minang, gelar Datuk tetap dipertahankan lalu dinisbahkan dengan masing-masing tempat pengabdian. Hal yang sama, dialami oleh para muballig 
menekankan pada ajaran tasawuf, sesuai kondisi masyarakat yang dihadapinya, yaitu masyarakat yang masih teguh berpegang kepada masalah-masalah kebatinan dan sihir. Masyarakat Tiro memiliki kegemaran dalam menggunakan kekuatan sakti (doti) untuk membinasakan musuh. Masyarakat demikian, menurut Datuk ri Tiro, akan lebih berhasil jika dilakukan pendekatan tasawuf.

Sebenarnya, bukan hanya tiga orang muballig dari Minangkabau yang datang di Makassar pada fase awal penerimaan Islam di wilayah ini tapi mencapai enam orang. Tiga orang selebihnya itu tidak bertugas di wilayah Propinsi Sulawesi Selatan sehingga namanya tidak masyhur di Makassar. Sulawesi Selatan pada waktu itu belum dikenal, namun Kerajaan Gowa di Makassar sudah mencapai wilayah kekuasaan yang ditempati ketiga muballig itu bertugas. Oleh karena itu penulis menyebut ada enam orang muballig Minangkabau yang datang di Makassar. Dua orang muballig itu adalah Datuk Karama, Datuk Mongaji dan Datuk Mohammad Tahir. Datuk Karama bertugas menyebarkan Islam di wilayah Kerajaan Banawa (sekarang meliputi Kabupaten Donggala, Kota Palu dan Kabupaten Sigi Propinsi Sulawesi Tengah) dan Datuk Mongaji bertugas di wilayah Kerajaan Parigi (sekarang meliputi Kabupaten Parigi Moutong Propinsi Sulawesi Tengah) dan Datuk Muhammad Tahir bertugas di Kerajaan Buol (sekarang Kabupaten Buol, pemekaran dari Kabupaten Toli-Toli Propinsi Sulawesi Tengah ${ }^{8}$.

Pendekatan mistik dalam permulaan dakwah sudah menjadi pola penyebaran Islam di Nusantara. Seperti halnya di pulau Jawa, pendekatan dakwah Walisongo mirip dengan pola ketiga Datuk di

di pulau Jawa yang terkenal dengan sebutan Walisongo, juga diberi gelar sesuai dengan tempat pengabdian dakwah mereka. Maulana Malik Ibrahim atau Makhdum Ibrahim AsSamarqandy bergelar Sunan Gresik. Raden Rahmat bergelar Sunan Ampel. Raden Makdum Ibrahim bergelar Sunan Bonang. Raden Qasim bergelar Sunan Drajat. Jaffar Shadiq bergelar Sunan Kudus. Raden Paku atau Ainul Yaqin bergelar Sunan Giri. Raden Said bergelar Sunan Kalijaga. Raden Umar Said bergelar Sunan Muria. Syarif Hidayatullah bergelar Sunan Gunung Jati.

${ }^{8}$ H.M. Noor Sulaiman, Islam di Tanah Kaili; dari Datokarama hingga SIS Aldjufri, (STAIN Datokarama Palu, 2001), h. 41. 


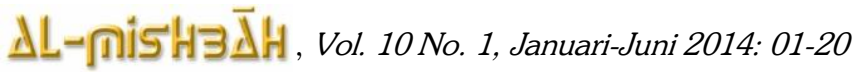

Sulawesi. Pendekatan dakwah kultural inilah yang berkembang di nusantara sehingga keislaman masyarakat Indonesia merasa tidak tercerabut dari akar budaya masing-masing. Perayaan hari-hari besar keagamaan seperti isra mi'raj, maulid, idul adha, idul fitri dan halal bi halal selalu ditampilkan dengan atraksi dan penampilan budaya setempat.

Setelah penyebaran Islam di tingkat masyarakat menunjukan keberhasilan, maka muballig sudah mulai memasuki kawasan istana. Tercatat Raja Gowa ke-14 I Mangngarangi I Daeng Manrabia memeluk agama Islam pada tahun 1603. Pengukuhan keberhasilan muballig mengislamkan sang raja, maka gelar "sultan" pun disandangkan kepada raja ini dengana nama Sultan Alauddin.

Dalam konstalasi global, nama sultan merupakan rangkaian peneguhan kekuasaan di bawah legitimasi Khilafah Turki Uthmani. Misi apapun yang dilakukan dalam setiap sektor, maka dorongan dan kekuatan ideologi menjadi bagian yang penting dari kegiatan itu. Para muballig di zaman itu, tentu mengetahui bahwa peran khilafah memiliki kekuatan adidaya. Namun di zaman itu pula gerakan kolonialis dari Eropa berhasil pula meruntuhkan kekuasaan khilafah.

Kesuksesan dakwah akan tercapai bilamana penguasa atau "orang terkuat" di negeri itu memeluk Islam. Seperti halnya setelah Umar bin Khattab masuk Islam, maka dakwah Nabi Muhammad SAW sudah mulai terang-terangan di Kota Makkah. Hal tersebut dibenarkan oleh teori, "Cuius regio, eius religio" (siapa pemilik negeri, dialah pemilik agama). Hal senada dikemukakan oleh Ibnu Khaldun, Annas 'Ala Din Almāliki (manusia atau rakyat mengikuti agama raja). ${ }^{9}$

Raja Gowa yang pertama memeluk Islam adalah I Mangarangi Daeng Manrabia Sultan Alauddin Tominanga ri Gaukana (1593 1639). Para muballig dengan kemampuan komunikasi politik yakni memberi gelar "sultan" pada raja yang berhasil di-Islam-kan. Masuknya muballig di istana kerajaan ini, merupakan langkah awal terjadinya pola,

${ }^{9}$ Ibnu Khaldun Abdurrahman bin Muhammad, Muqaddimah, (Jakarta : Putaka Firdaus, 1992), h. 24. 
peran dan status baru dalam sistem sosial kemasyarakatan. Di antara prinsip umum tentang kebijakan Datuk ri Bandang dalam program islamisasi adalah beliau menghindari suatu perubahan yang bisa menggoyahkan sendi-sendi kehidupan sosial. Karena itu, Datuk ri Bandang tidak melakukan perobakan pada struktur pemerintahan yang sudah ada, melainkan melengkapinya dengan memasukkan pranata atau lembaga Islam ke dalam struktur itu.

Lembaga sarak ${ }^{10}$ diadakan setelah Islam diterima secara resmi menjadi agama kerajaan pada tahun 1607. Pemimpin tertinggi dalam lembaga sarak adalah Daeng To Kaliya (Makassar) atau Petta Kalie (Bugis). ${ }^{11}$ Dalam menjalankan tugas sehari-hari, Daeng To Kaliya dibantu oleh beberapa orang pejabat di bawahnya, yaitu Daeng Imang, Guruwa, Katte, Bidala, dan Doya atau Jannang Masigi. ${ }^{12}$ Penghasilan mereka sebagai parewa sarak (aparat agama), ada yang diperoleh dari penghsilan resmi kerajaan dan sebagian diperoleh langsung dari masyarakat. Daeng To Kaliya mendapat penghasilan resmi dari kerajaan, sedang para aparat di bawahnya, seperti imang, katte, guruwa, bidala dan doya memperoleh penghasilan dari masyarakat melalui pembayaran zakat fitrah, zakat, infak dan sedekah.

${ }^{10}$ Sarak (dialek Makassar) dari kata "shari'at", dimaknai sebagai pedoman pelaksanaan ajaran Islam. Jadi lembaga sarak adalah struktur dalam pemerintahan yang mengerjakan hal-hal yang berkaitan dengan ajaran Islam seperti nikah, aqiqah, pengurusan masjid, penyelenggaraan jenazah dan kegiatan ibadah lainnya.

${ }^{11}$ Daeng dan Petta adalah kebangsawanan tertinggi di masyarakat Makassar dan Bugis. Dengan demikian, tampak pengaruh stratifikasi sosial Bugis Makassar dalam institusi Islam.

${ }^{12}$ Imang dari Bahasa Arab "Imām". Itulah dialek Bugis Makassar yang selalu berdesis "ng" di akhir kata berhuruf "m" dan "n". Guruwa, nama panggilan "guru" (orang yang mengajarkan Alqurān dan dasar-dasar ajaran Islam, seperti tayammum, wudhu dan shalat. Sedangkan pengajaran syahadat, puasa, zakat, haji dan muamalah masuk dalam wilayah otoritas Daeng Imang. Katte dari kata "khatib" (orang yang menyampaikan khutbah Jum'at). Bidala dari kata "bilal" (orang yang mengumandangkan azan setiap memasuki waktu shalat). Sedangkan doya atau jannang masigi adalah orang yang bertugas pada keamanan dan kebersihan masjid. 


\section{$\Delta$ L-nis H $3 \bar{\Delta} h$, Vol. 10 No. 1, Januari-Juni 2014:01-20}

Adapun struktur lembaga sarak dalam struktur Kerajaan Gowa adalah sebagai berikut ${ }^{13}$ :

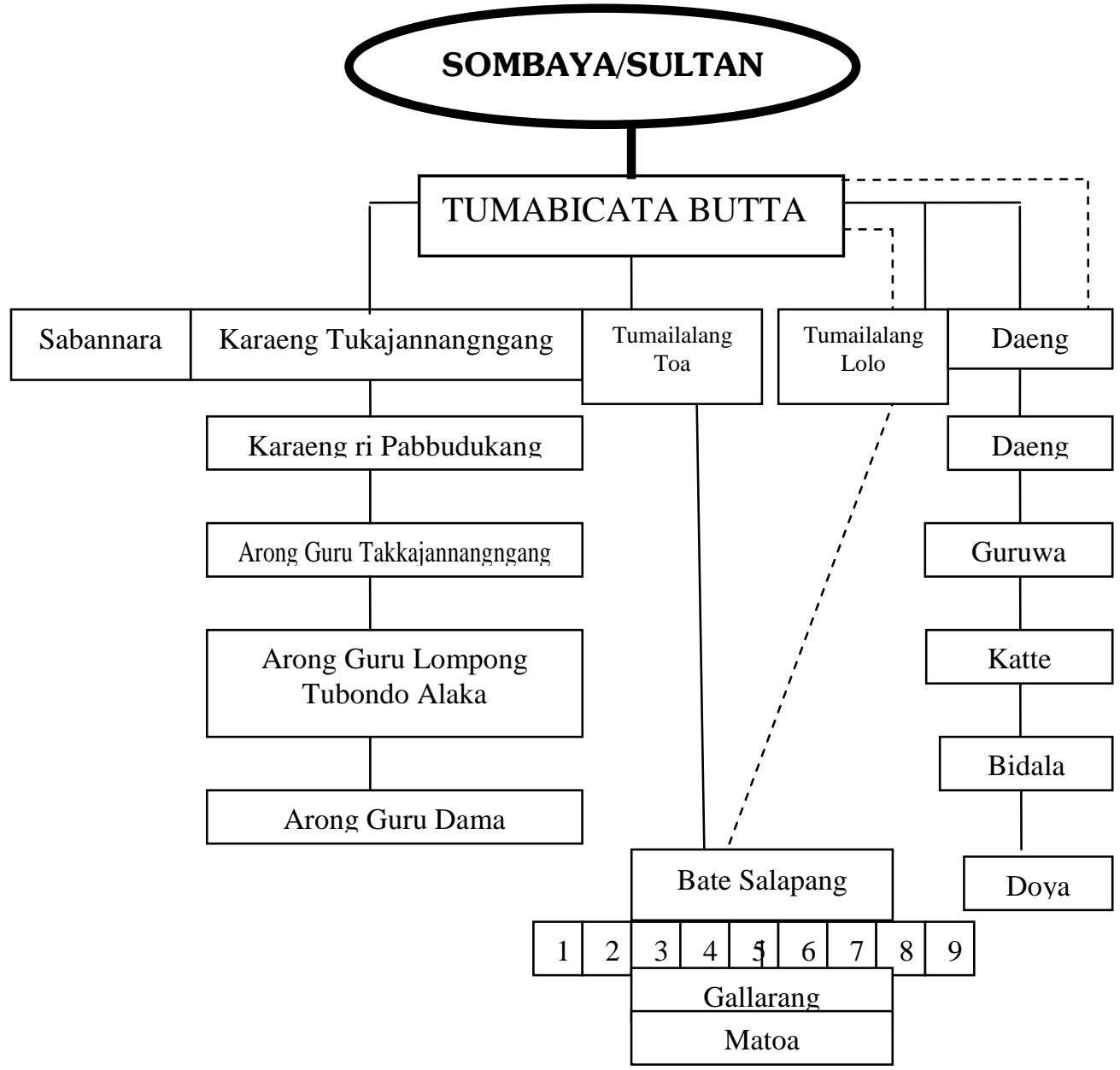

Keterangan :

$=$ Garis Instruksi

= Garis Konsultasi

Gambar 2.3. Struktur Kerajaan Gowa Setelah Penerimaan Islam

${ }^{13}$ Ahmad M. Sewang, op. cit., h. 93. 
Gambar di atas menunjukkan bahwa betapa besarnya perhargaan sosial politik oleh institusi kerajaan kepada pemangku wilayah keagamaan. Penghargaan itulah yang terus menerus dilakukan oleh institusi pemerintahan dan umat Islam kepada lembaga-lembaga keagamaan yang sekarang dijalankan oleh para muballig. Setelah hegemoni kerajaan berangsur-angsur melemah seiring dengan pendudukan kolonial lalu memasuki fase kemerdekaan Negara Kesatuan Republik Indonesia, institusi kerajaan sekarang diadopsi menjadi lembaga adat sedangkan institusi keagamaan berdiaspora ke wilayah kewenangan otoritas muballig dan lembaga-lembaga agama lainnya.

\section{Fase Ideologisasi Islam}

Kebenaran agama Islam yang diyakini oleh para pembesar istana Kerajaan Makassar memunculkan sikap fanatisme dan gelora dakwah yang begitu membuncah, seolah-olah surga sudah berada di pelupuk mata ketika seseorang sudah memeluk Islam. Pihak Kerajaan Makassar ingin menyampaikan ajaran Islam kepada kerajaan-kerajaan di sekitarnya.

Pada hari Jumat tanggal 9 Nopember 1607 Miladiyah (Masehi) bertepatan 19 Rajab 1016 Hijriyah, Sultan Alauddin mendekritkan di hadapan jamaah Jum'at bahwa Kerajaan Gowa sebagai kerajaan Islam dan menjadikan kerajaannya sebagai pusat islamisasi di Sulawesi Selatan. Untuk merealisasikan dekrit itu, Sultan Alauddin mengirim utusan ke kerajaan-kerajaan tetangga di Sulawesi Selatan. Sejumlah kerajaan yang didatangi oleh para utusan menyambut mereka dengan damai, seperti Kerajaan Sawitto di Pinrang, Kerajaan Balanipa di Mandar, serta kerajaan-kerajaan di Bantaeng dan Selayar. Penerimaan Islam di Balanipa, mandar berlangsung damai. Hal ini dapat dipahami karena hubungan antara mandar dengan Gowa sudah terjalin baik sebelumnya, baik hubungan kekeluargaan maupun hubungan kerjasama di bidang politik. ${ }^{14}$

\footnotetext{
${ }^{14}$ Ibid., h. 113.
} 


\section{$\Delta$ L-nis $H \exists \vec{\Delta}$ H. Vol. 10 No. 1, Januari-Juni 2014:01-20}

Lain halnya dengan kerajaan-kerajaan yang tergabung dalam persekutuan Tellunpoccoe, yaitu Kerajaan Bone, Kerajaan Soppeng dan Kerajaan Wajo yang disingkat dengan adagium BOSOWA ${ }^{15}$ menolak ajakan Kerajaan Makassar. Penolakan mereka didasarkan pada asumsi bahwa ajakan itu sebagai taktik untuk memenuhi ambisi Gowa dalam memulai ekspansi dan dominasi di bidang politik dan ekonomi di seluruh kerajaan Tellunpoccoe. Jadi, Tellunpoccoe tidak percaya bahwa penyampaian Islam oleh Gowa bukanlah didasarkan pada ketulusan melainkan bersifat politis. ${ }^{16}$

Spirit of Islam (semangat untuk menyebarkan Islam) yang menyebabkan berkobarnya perang antara Kerajaan Gowa dengan persekutuan Tellonpoccoe. Mattulada mencatat peperangan itu berlangsung dari tahun 1607 hingga 1666. Serangan-serangan pasukan Gowa terhadap kerajaan-kerajaan Tellunpoccoe dilakukan dalam dua arah, yaitu melalui arah barat ke daerah Sawitto dan Rappang, kemudian dari arah selatan melalui Tanete dan Barru. ${ }^{17}$

Pada tahun 1607, pasukan Gowa yang melalui arah barat pertama-tama mendarat di Sawitto, Pinrang, di tempat yang kemudian dinamai Binanga Karaeng (sungai tempat pendaratan Raja Gowa). Dari sana, kemudian mereka meneruskan perjalanannya ke Suppa dan Sidenreng. Di daerah ini, tentara Gowa mendapat perlawanan gigih dari pasukan Tellunpoccoe. Dalam pertempuran di Ajattappareng, pasukan Gowa mengalami kekalahan sehingga mereka harus mengundurkan diri. $^{18}$

${ }^{15}$ Bosowa kini lebih populer karena dijadikan branding perusahaan oleh kelurga Kalla di Makassar. Bosowa Group meliputi usaha penjualan mobil merek Mitsubishi, pabrik semen, penerbitan media Fajar Group, air mineral, pertanian, perkebunan dan perikanan.

${ }^{16}$ Ibid.

${ }^{17}$ Mattulada, Menelusuri..., h. 222.

${ }^{18}$ Ibid. 
Tiga bulan setelah perang Ajattappareng, Raja Gowa kembali medaratkan pasukannya di tiga tempat, yaitu Akkotengeng, Maroanging dan Padaelo. Pendaratan yang kedua ini, berhasil mempengaruhi masyarakat Akkotengeng untuk memihak pada Gowa. Pemihakan tersebut sangat merugikan persekutuan Tellunpoccoe. Akibatnya, satu persatu daerah di Tellunpoccoe jatuh ke tangan pasukan Gowa. Pada tahun 1608, Rappang, Bulu Cenranae, Utting dan Maiwa berpihak pada Gowa. Jatuhnya daerah-daerah tersebut, memberi kesempatan pada Gowa untuk menghimpun kekuatan dengan mendirikan benteng pertahanan di Rappang, sehingga setiap serangan dari Tellunpoccoe selalu dapat dihalau oleh pasukan Kerajaan Gowa. Kekalahan Tellunpoccoe menyebabkan banyak orang Wajo datang menghadap kepada Raja Gowa di Rappang untuk memeluk agama Islam. ${ }^{19}$

Selanjutnya pada tahun 1609, Gowa melakukan serangan yang kedua melalui arah selatan, yaitu dari arah Tanete menyerang ke Soppeng. Serangan Gowa ini tidak mendapat perlawanan yang berarti, sehingga dengan mudah orang-orang Lamuru dan Marioriawa menyerah kepada Gowa. Datu Soppeng sendiri masuk Islam pada tahun 1609. Melihat jalannya peperangan yang sudah mulai berbalik arah dengan kemenangan di pihak Gowa, Arung Matowa Wajo segera mengambil langkah damai dengan mengirim surat perdamaian kepda Raja Gowa, Sultan Alauddin. Arung Matowa tidak keberatan menerima Islam, dengan syarat, sebagaimana dilukiskan dalam bahasa Bugis, "Tennareddumui wasseku, tennatimpa' salewoku, tennasese' balaoritampukku" (tidak merampas kerajaanku, tidak mengambil barang-barang kepunyaan rakyatku dan kepunyaanku). ${ }^{20}$

Sultan Alauddin menerima persyaratan itu, sehingga Arung Matoa, La Sangkuru serta rakyatnya memeluk agama Islam pada tahun 1610. Pengakuan Arung Matoa dari Wajo terhadap kekuasaan Gowa, berarti tinggal satu kerajaan Tellumpoccoe yang masih bertahan dan
${ }^{19}$ Ibid.
${ }^{20}$ Ibid. 


\section{$\Delta$ L-nis $H \exists \vec{\Delta}$ H. Vol. 10 No. 1, Januari-Juni 2014:01-20}

memberikan perlawanan, yaitu Kerajaan Bone. Pasukan Gowa sudah tidak lagi mengalami kesukaran menghadapinya, karena dengan takluknya Soppeng dan Wajo, berarti Gowa sudah bisa mengonsentrasikan kekuatan perangnya terhadap Bone. Sebelum pengerahan kekuatan bersenjata, Raja Gowa terlebih dahulu mengirim utusan kepada Arungpone La Tenrirua, Raja Bone XI, agar menerima Islam secara damai. La Tenrirua menanggapinya dengan mengumpulkan rakyatnya dan menyampaikan hal itu kepada mereka. Penyampaian Raja Bone kepada rakyatnya itu, dilukiskan sebagai berikut :

"Sekarang ini Raja Gowa datang kepada kita membawa agama Islam yang akan membawa kita menuju kepada kebaikan dan kepada cahaya yang gilang gemilang. Sebab antara Gowa dan Bone telah diadakan perjanjian, bahwa barang siapa di antara keduanya yang mendapat sinar yang terang dan jalan menuju kepada kebaikan, maka dialah yang memberitahukan itu kepada lainnya" ${ }^{21}$.

Mendengar penyampaian Raja Bone itu, rakyat tidak menerima dan menganggap Arungpone sebagai pengkhianat. Untuk menenangkan keadaan, Arungpone meninggalkan ibukota kerajaan menuju Pattiro. Setelah dilakukan berbagai perundingan antara pemuka Kerajaan Bone denga Arungpone, akhirnya diputuskan untuk mencari pengganti La Tenrirua dengan dinobatkannya La Tenripale Tuakkapeang, Arung Timurung sebagai Raja Bone XII.

La Tenrirua kemudian menyatakan masuk Islam dan bersamasama dengan pasukan Kerajaan Gowa menyerang La Tenripale Toakkapeang. Pada tahun 1611, Kerajaan Gowa berhasil mengalahkan Bone. Sebagaimana biasanya, setelah suatu kerajaan dikalahkan, maka raja dan rakyatnya memeluk Islam. Demikian halnya Kerajaan Bone, setelah dikalahkan dalam perang, Raja Bone La Tenripale Toakkapeang,

${ }^{21}$ Ibid., h. 118. 
bersama rakyatnya masuk Islam pada tahun $1611 .^{22}$ Dengan diterimanya Islam oleh Kerajaan Bone, dapat dikatakan bahwa seluruh wilayah Sulawesi Selatan (sekarang) menerima Islam, kecuali Tana Toraja.

Penerimaan Islam Kerajaan Bone juga memberikan arti tersendiri bagi Gowa, sebab untuk pertama kalinya Gowa dapat menguasai kerajaan-kerajaan Bugis secara keseluruhan. Semangat jihad (kewajiban suci untuk berdakwah) mengantarkan Gowa menaklukkan Bone yang memang sudah menjadi musuh bebuyutan yang tidak pernah berhenti. Pengaruh Islam yang sudah menglobal pada waktu itu, Bone sudah pasti tidak mampu melawannya. Menerima Islam segera menjadi ajang pergantian identitas untuk bertahan dalam pertarungan kehidupan (survival of the fittes). ${ }^{23}$

${ }^{22}$ Secara natural Raja Bone yang pertama masuk Islam adalah We Tenri Tappu yang bergelar La Maddusila. Dia adalah Raja Bone X, memerintah antara tahun 1602-1611. Dia masuk Islam pada tahun 1610 dan sengaja datang ke Sidenreng untuk mempelajari agama Islam. Sayang sekali, dia diserang penyakit dan meninggal di Sidenreng. Meskipun dia sudah memeluk Islam, tetapi kerajaannya belum secara resmi dinyatakan sebagai kerajaan Islam. Dia adalah salah seorang raja peremuan (ratu) dari tujuh ratu yang pernah memerintah Kerajaan Bone.

${ }^{23}$ Hal itu terjadi pula pada zaman Nabi Muhammad SAW di Makkah, yang salah satu penantangnya adalah Abu Sufyan. Begitu Nabi hijrah ke Madinah dan berhasil merebut kekuasaan di semenanjung Arabia setelah melewati peperangan demi peperangan seperti perang Badar, perang Uhud dan lain-lain. Kejayaan di Madinah, membuat Nabi ingin melihat tanah kelahirannya Makkah sekaligus menaklukkannya yang kemudian terkenal dengan Fathu Makkah (pembebasan Makkah). Abu Sufyan sudah tidak mampu menghadapi bala tentara Nabi sehingga ia "angkat tangan". Namun Nabi berseru bahwa siapa saja orang Makkah yang masuk di rumah Abu Sufyan maka ia selamat. Tidak lama setalah Fathu Makkah, Nabi wafat. Pemerintahan Madinah diteruskan oleh Abu Bakar Ash-Shiddiq kemudian Umar bin Khattab lalu Usman bin Affan dan selanjutnya Ali bin Abi Thalib. Lihat Keith A. Francis, Charles Darwin and The Origin of Species, (London : Greenword Press, 2007), h. 43. Keluarga Abu Sufyan masih "tiarap" namun masih beruntung karena salah satu putranya diangkat menjadi Gubernur Damaskus yaitu Muawiyah bin Abu Sufyan di zaman Khalifah Usman bin Affan. Benihbenih kekuasaan mengantarkan Muawiyah untuk merebut kekuasaan khilafah yang sangat menggiurkan itu karena bukan hanya sebatas Makkah tapi sudah meliputi seluruh tanah-tanah Arab. Muawiyah pun melakukan perang dengan Ali bin Abi Thalib. Perang antara gubernur dengan presiden. Pasukan Muawiyah tentu tidak mampu melawan 


\section{$\Delta$ L-nis $H \exists \vec{\Delta}$ H. Vol. 10 No. 1, Januari-Juni 2014:01-20}

Masuknya Islam di daerah Bugis ternyata menjadi jembatan untuk penyiaran Islam ke se-antero Sulawesi. Penelitian Sulaiman (2001) mengemukakan bahwa orang Bugislah yang pertama kali menyiarkan di Islam di Sulawesi Tengah. Hal itu ditunjukkan dengan metode pengajaran Alqurān yang menggunakan ejaan bahasa Bugis, pada di sana bahasa daerah adalah bahasa Kaili. Metode Baghdadi yang kemudian muncul Metode Iqrā memang digubah oleh orang Bugis dengan bahasanya sendiri yang antara lain berbunyi, alefu diasenna a (alefu berbaris fatah berbunyi a), alefu diawana $i$ (alefu berbaris kasrah berbunyi i), alefu diafanna $u$ (alif berbaris dommah berbunyi u. Kalau metode itu diaplikasikan dalam membaca Alqurān maka hasilnya demikian. Contoh cara eja ala Bugis adalah alefu mpuno lameng

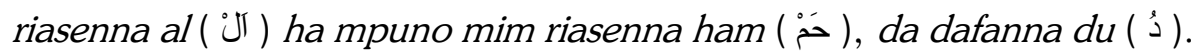

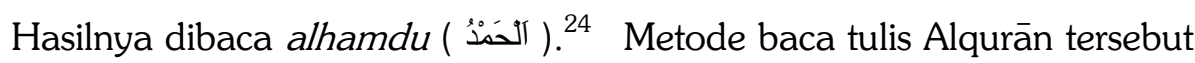
dikenal dengan nama Kaidah Baghdadiyah (Metode Baghadadi). Kini perkembangan ilmu pengetahuan dan teknologi, metode baca tulis Alqurān semakin banyak jenisnya. Seperti Metode Al-Barqi ${ }^{25}$, Metode Iqrä $^{-26}$, Metode Qirā'ah ${ }^{27}$ dan lain-lain.

Misi Sultan Alauddin menyiarkan Islam Islam di wilayah Tellunpoccoe dengan peperangan, di sisi lain telah berjasa di bidang dakwah, namun di sisi lain dengan kekerasan tersebut tetap saja menanamkan rasa dendam bagi kelurga raja Bone lainnya. Raja Bone XIV La Tenritatta Arung Palakka Petta Malampee Gemmenna Arung

pasukan Ali, lalu Muawiyah meminta perang dihentikan dan meminta untuk berunding. Dengan kelicikan Muawiyah mampu mengalahkan Ali dan bertahtalah Muawiyah sekaligus merubah khilafah yang demokratis menjadi monarki (kerajaan) dengan nama Dinasti Umayyah. Ibukota pun dipindahkan dari Madinah ke Damaskus.

${ }^{24}$ H.M. Noor Sulaiman, Islam di Tanah Kaili ; dari Datokarama hingga SIS Aldjufri, (Palu: STAIN Datokarama, 2001), h. 23.

${ }^{25}$ Muhadjir Sulthon, Metode Al-Barqi, (Surabaya: IAIN Sunan Ampel, 1965), h.

2.

${ }^{26}$ As'ad Humam, Buku Iqra, (Yogyakarta : Angkatan Muda Masjid, 1990), h. 5.

${ }^{27}$ Andi Suriadi, Buku Qiraah, (Makassar : Faslamia, 2001), h. 1. 
Tungkenna Tana Ugi, tetap menganggap penjajahan Kerajaan Gowa atas Kerajaan Bone. Arung Palakka kemudian menabuh genderang perang melawan Raja Gowa.

\section{D.Penutup}

Gerakan penyiaran dakwah di Makassar dilaksanakan oleh para saudagar dengan memanfaatkan media perdagangan untuk menyampaikan ajaran Islam. Masyarakat menyambut antusias misi itu, karena memang belum ada ajaran agama samawi yang permanen dianut oleh orang Bugis Makassar. Kepercayaan sebelumnya berupa persembahan kepada dewi padi "Sang Hyang Seri", sudah mulai ditinggalkan oleh kaum pedagang Bugis Makassar yang melakukan peruntungan hidup di kota.

Melihat gerakan massif sang kawula rakyat memeluk Islam, sang raja pun harus ikut serta memeluk Islam. Kerajaan Gowa adalah kerajaan pedalamam, sedangkan Kerajaan Tallo berada di basis maritim. Hal ini mendorong Raja Gowa Sultan Alauddin untuk melakukan pendekatan kepada Raja Tallo Sultan Awwalul Islam untuk menyatukan dua kerajaan. Persekutuan dua kerajaan itu disebutlah Kerajaan Makassar, yang namanya terkenal dan terkenang hingga sekarang.

Makassar sebagai kawasan maritim menjadi magnet kekuasaan bagi raja-raja terdekat seperti Kerajaan Bone, Kerajaan Wajo, Kerajaan Luwu, Kerajaan Mandar, Kerajaan Tana Toraja dan lain-lain. Jejak manusia alias rakyat bekas-bekas kerajaan itu, yang kini memenuhi Kota Makassar. 


\section{$\Delta$ L-nis H $3 \vec{\Delta}$ H H Vol. 10 No. 1, Januari-Juni 2014:01-20}

\section{Daftar Pustaka}

Abdurrahman bin Muhammad, Ibnu Khaldun, Muqaddimah, (Jakarta: Putaka Firdaus, 1992).

Francis, Keith A., Charles Darwin and The Origin of Species, (London: Greenword Press, 2007

Humam, As'ad, Buku Iqra, Yogyakarta: Angkatan Muda Masjid, 1990.

Mattulada, Menyusuri Jejak Kehadiran Makassar Dalam Sejarah, (Makassar: Universitas Hasanuddin, 1983).

Sewang, Ahmad M., Islamisasi Kerajaan Gowa Abad XVI Sampai Abad XVII, (Jakarta: Yayasan Obor Indonesia, 2005).

Suriadi, Andi, Buku Qirāah, Makassar: Faslamia, 2001.

Sulthon, Muhadjir, Metode Al-Barqii, Surabaya: IAIN Sunan Ampel, 1965.

Sulaiman, H.M. Noor, Islam di Tanah Kaili; dari Datokarama hingga Sis Aldjufri, (STAIN Datokarama Palu, 2001).

Suryanegara, Ahmad Mansur, Menemukan Sejarah, (Bandung: Mizan, 1995).

Taliu, H.M., Sekilas dari Sebagian Kerajaan Otonomi yang pernah ada di Sulawesi Selatan, (Pangkajenne Kepulauan, Dinas Pendidikan Nasional, 2003). 